\title{
Walking in the Dark: \\ Lack in the Use of Criminal Statistics for \\ Public Policy and Legislative Actions
}

\section{Abstract}

Simeneh Kiros Assefa *

As an exercise of sovereign power, the lawmaker adopts public policies to achieve certain ends. However, public policies need justifications. One such public policy is criminalisation of conduct whereby the lawmaker may have to use both doctrinal and empirical justifications. Such empirical justification is criminal statistics. All the three organs - the police, the prosecution office and the court - are required by law to collect and keep criminal statistics. Statistical data may not be available for initial adoption of legislation; yet they are essential inputs during the revision process. Even though criminal statistics do not define the outcome of the decision of the lawmaker, one would expect that they would be used as one major input for the continuous evaluation of such law. This article examines the use of criminal statistics in the adoption/revision of criminal provisions and finds that no criminal statistics is presented in the legislative process. This appears to be for two reasons. First, the various bills were drawn up and presented by agencies claiming to have specialisation on the subject; often, such agencies do not possess criminal statistics. Second, even for those bills drawn up by agencies with potential criminal statistics, the lawmaking process is skewed, that it does not demand aspiration to make 'good' laws.

\section{Key terms}

Criminal statistics - Criminalisation - Legislative reform - Legislative rationality

DOI http://dx.doi.org/10.4314/mlr.v12i2.6

This article is licensed under a Creative Commons Attribution-NonCommercialNoDerivs (CC BY-NC-ND)

\section{Introduction}

Public policy decisions are made to attain certain social, political and economic ends. Criminal law is one such tool of social control and criminalisation is one such public policy decision. When the government decides to criminalise a

* Simeneh Kiros Assefa: LL.B (Addis Ababa University), LL.M (University of Pretoria), LL.M (Kyushu University), LL.M (University of San Francisco); Assistant Professor of Law at AAU Law School, Attorney-at-Law and member of California State Bar (inactive). I thank Hirko Alemu for his extraordinary assistance in data collection. Email: simeneh@simenehlaw.com 
particular conduct, it may be guided by normative (doctrinal) and empirical standards. Criminalisation of conduct is made based on the basic assumption that the criminal law deters such conduct of potential actors. Once the conduct is criminalised, such legislation remains under constant potential revision; such evaluation is made based on evidence of the need to reform. ${ }^{1}$ One such evidence is criminal statistics. The criminal statistics may be used, as part of the public policy revision, to criminalise or to decriminalise conduct, and to increase or to decrease the punishment for such crime.

Such data may be collected at different stages of the process. It may be collected by the police, the office of the Attorney General or the court. Each of them may report to the House of Peoples' Representatives about their performance. Included in the report is the analysis and presentation of criminal statistics, which is required by law to be a part of 'the report'. In this report, those agencies presumably identify problems and challenges in the administration of the criminal justice for which they need to provide solutions. If one of the solutions is legislative action, it is the Attorney General's Office as the legal advisor of the Federal Government- that proposes such public policy action (of criminalisation or decriminalisation, increase or decrease of criminal punishment) in order to address such identified social ill.

However, there are two major shortcomings regarding the practice of use of criminal statistics. First, there are no records that show data were properly collected and utilised for such public policy action. Second, sometimes, the agency which recommends legislative action is not the Federal Attorney General (formerly Ministry of Justice), the legal advisor for the Federal Government. Depending on their claimed area of expertise, it is other administrative agencies, such as, the Ministry of Trade and Industry, and Ministry of Finance and Economic Development, who do not possess such data and could not establish the facts for proper action by the legislative body that propose a bill. ${ }^{2}$

\footnotetext{
${ }^{1}$ Wintgens cogently argues that the law should not only be formally valid in its initial adoption, but it must also be effective in order to justify its continued existence. A norm may become effective and justify its continued existence when it is supported by the facts. When a given norm is not supported by the facts, the legislator needs to react; otherwise, the norm becomes unconstitutional by mere passage of time and change of circumstances. L.J. Wintgens (2013) "The Rational Legislation Revisited. Bounded Rationality and Legisprudence" In L.J. Wintgens and A.D. Oliver-Lalana (Eds.) The Rationality and Justification of Legislation: Essays in Legisprudence, Heidelberg: Springer, 24, 26-28.

${ }^{2}$ Arts 30 and 38 of the Council of Ministers Working Directives (Addis Ababa, 2003) authorise every Minister to have the power and responsibility to initiate policies and laws, regarding the Ministry s/he leads. This, in turn gives the impression that only the government agencies initiate bills. See the process of the adoption of laws under art 40 . Further, art 43 provides that such draft bills shall be drawn up by professionals of such agency. This is what is referred to as 'Government Draft Law' in the Federal Democratic
} 
This article discusses how criminal statistics can be used as a justification in criminal legislative reform. The first section deals with the need for criminal statistics, and the circumstances that necessitate the utilisation of criminal statistics. Section 2 discusses the institutions with legal and practical competence to collect criminal statistics which also defines the nature of data to be collected. Section 3 addresses the utilisation of such data by the respective institutions, for various purposes including legislative reform. Section 4 examines the practices of using of such criminal statistics in this legislative reform.

In order to put matters in context regarding the normative and empirical justifications for reform, the article examines areas of penal legislation relatively frequently reformed, such as, vagrancy law, tax laws, commercial registration and trade license, and crimes of terrorism. Deliberately excluded are legislations relating to corruption only for intelligibility of the discussion. Section 5 makes general observations regarding the legislative reform process and use of criminal statistics. The discussion is made based on the frequently revised penal provisions, explanatory memorandum to the revision, and minutes of public and parliamentary hearings.

\section{General Background}

The criminal law is the most effective social control tool discovered yet. It is believed to have a deterrent effect on potential actors. Thus, it is used to guide the behaviour of citizens in a desired way. As such, it is a prospective norm that states the prohibited conduct the violation of which entails a consequence, usually, punishment. Both the prohibition and the punishment are determined by the lawmaker with a view to achieving certain social, political and economic ends. ${ }^{3}$ There are several laws with such objectives in mind, whether it is meant for the maintenance of law and order or demanding the individual to comply with administrative decisions. ${ }^{4}$

Republic of Ethiopia House of Peoples' Representatives Working Procedure and Members' Code of Conduct (Amendment) Proclamation No 470/2005, art 2(18). Even though this legislation lists about 7 organs as having the power to initiate bills (art 6(2)), all legislation containing penal provisions were initiated by agencies only.

3 This is the principle of legality that the prohibited conduct, the consequences of the violation must be pre-declared and made known to the public through the regular official gazette. Crim. C., art 2. Simeneh Kiros Assefa (2017) "Methods and Manners of Interpretation of Criminal Norms" In 11 Mizan L. Rev. No 1, at 104-107.

4 The recent trends of criminal enforcement of administrative decisions through penal provisions is observed in our discussion on over-criminalisation. Simeneh Kiros Assefa and Cherinet WordofaWetere (2017) “'Over-Criminalisation': A Review of Special Penal Legislation and Administrative Penal Provisions in Ethiopia" in 29 J. Eth. L. No 1. 
However, it is always the case that the criminal law has a subsidiary function, i.e., it is used when the interest that needs legal protection is an essential interest and it cannot effectively be protected by the administrative measures or civil actions. ${ }^{5}$ Therefore, in criminalising a certain conduct, the legislature should first establish whether both the positive and negative requirements are met. As this has never been a point of discussion in any of the criminal legislation adopted so far, the discussion in this article is whether the lawmaker examines evidence of practice when revising a particular legislation and examines the kind of criminal statistics it makes use of.

For instance, the Vagrancy Control Proclamation states that it is adopted because vagrancy had been "increasing and wide-spreading in the country from time to time, thereby creating a threat to the tranquility and order of the people." Therefore, the Proclamation had been adopted to "permanently dispel this threat". Likewise, the Anti-Terrorism Proclamation states that "it has become necessary to legislate adequate legal provisions since the laws presently in force in the country are not sufficient to prevent and control terrorism." 8

The preambles of these laws indicate that the already existing legislation or provisions are not able to meet their objectives of prevention of vagrancy crimes and crimes of terrorism, respectively. Therefore, the decision to adopt such special penal legislation would have to be based on evidence, one of which, most certainly, is criminal statistics that show rising number of vagrancy and terrorism crimes, instead of just stating that vagrancy or terrorism is 'increasing' or becoming 'widespread'.

Likewise, the Commercial Registration and Trade License Proclamation is continuously revised and contains progressively increased punishments. It has also expanded the scope of criminalised conducts. Initially, criminalisation of trading without a valid permit was introduced in the Commercial Registration and Business Licensing Proclamation No 67/1997 (Commercial Registration Proclamation No 67/1997"). It was punishable with imprisonment from 3 to 5

\footnotetext{
${ }^{5}$ This is essentially the principle of ultima ratio. See generally, A.M.P. del Pino (2016) "The Proportionality Principle in a Broad Sense and Its Content of Rationality: The Principle of Subsidiarity" in A.N. Martin and M.M. de Morales Romero (Eds.) Towards a Rational Legislative Evaluation in Criminal Law, Switzerland: Springer. M.D. Dubber (2005) "Theories of Crime and Punishment in German Criminal Law" in 53 Am. J. of Comp. L., No 3. D. Husak (2004) "The Criminal Law as Last Resort" in 24 Oxford J. of Legal Studies No 2. S. Mir Puig (2008) "Legal Goods Protected by the Law and Legal Goods Protected by the Criminal Law, as Limits to the State's Power to Criminalize Conduct" in $11 \mathrm{New}$ Crim. L. Rev.: An Int'l and Interdisciplinary J., No 3.

${ }^{6}$ Vagrancy Control Proclamation No 384/2004, preamble, para 1.

${ }^{7}$ Id., para 2.

${ }^{8}$ Anti-Terrorism Proclamation No 652/2009, preamble, para 3.
} 
years and fine twice of the profit said to have been earned. The penalty was increased in Commercial Registration and Business Licensing Proclamation No 686/2010 ("Commercial Registration Proclamation No 686/2010") to rigorous imprisonment from 5 to 15 years, to fine from Birr 150,000 and Birr 300,000, and confiscation of the production or service rendering materials. Then range of conducts criminalised were expanded in Commercial Registration and Business Licensing Proclamation No 980/2016 ("Commercial Registration Proclamation No 980/2016"). In such reforms, one would expect data presented to lawmaker that shows the penal provisions have failed to achieve the intended purpose.

There are two caveats that are worth mentioning here. The first caveat is to note that criminal statistics are about crimes committed and they do not show anything regarding crimes not committed. Second, in continental system, the rationale for a particular rule is found in the preamble. Often, in administrative regulatory proclamations containing penal provisions, the preamble states justifications and objectives of the proclamation. However, it does not contain such justifications for the penal provisions. The objectives of those penal provision may, however, be abstracted from the General Part of the Criminal Code. Thus, there is significant divergence of objectives of the legislation and those penal provisions contained therein. Further, the rationale for the revision may be found in the preparatory works.

Criminalisation and determination of sentence to such conduct violating such prohibition is a public policy decision. ${ }^{9}$ It is quintessential state's coercive power. It is believed that the lawmaker desires to make a rational and effective legislation. This is because the lawmaker exercises a constitutional power, which is believed to be limited by the constitution, and is exercised wisely. ${ }^{10}$ The lawmaking power may, therefore, be seen from the perspective of the notion of limited government.

\footnotetext{
${ }^{9}$ See generally, A.M. Arenas (2016) "Theoretical and Procedural Aspects of the Evaluation of Public Policies" In Martin and de Morales Romero (Eds.), supra note 5.

${ }^{10}$ See for instance, Wintgens (2013), supra note 1. Also see, A. Kristan (2013) "Three Grounds for Tests of the Justifiability of Legislative Action: Freedom, Representative Democracy, and Rule of Law" in Wintgens and Oliver-Lalana (Eds.), supra note 1. H. Isola-Miettinen (2013) "The Principles Legislative Strategy: Rationality of Legal Principles in the Creation of Laws?" in Id.; J. Sieckmann (2013) "Legislation as Implementation of Constitutional Law: A Foundation of the Demand of Legislative Rationality" in Id.
} 


\section{Institutions Collecting Criminal Statistics and the Nature of the Information}

In the establishment proclamations of the respective institutions, it is a part of their duties and responsibilities that the Police, the Attorney General Office, and the Court collect data and analyse and make it an input to discharge their fundamental obligations, such as, crime prevention, and make it part of their report to the House of Peoples' Representatives. However, even though the data to be collected appear to be different (because of the nature of the obligations), those data lead to the formation of shared opinion regarding the administration of the criminal justice.

\subsection{Institutions collecting criminal statistical data}

The Police - The Federal Police has three fundamental responsibilities in the administration of the criminal justice. It has the principal responsibility of prevention of crimes. ${ }^{11}$ As such, the major part of the budget is allocated to deploy police force on the ground. ${ }^{12}$ Once a crime is said to be committed, the police have the duty to investigate such crime and forward the investigation report to the Attorney General office for prosecution. ${ }^{13}$ The Federal Police conducts investigation on those crimes that are said to fall under the jurisdiction of the Federal Courts. It has organised its activities under two categories: technical and tactical investigation. While the technical investigation is all about expertise, such as, finger prints, document examination and arson investigation, the tactical investigation refers to the ordinary investigation. The latter is,

${ }^{11}$ Ethiopian Federal Police Commission Establishment Proclamation No 720/2011(“Federal Police Proc No 720/2011"), art 6(1), (4).

12 The Federal Police was granted budget separately in 1994 E.C (July 2001/June 2002). Its annual budget was Birr 1,365,800. In 2001 E.C. (July 2008/June 2009) this amount grew to Birr 20,445,100. In the same period, the Budget allocated to the Ministry of Justice was Birr 5,831,000 and 14,516,600, respectively. The budget allocated to the Federal Courts is Birr 17,891,200 and 26,448,500, respectively. There are two caveats to this number. First, the Federal Courts are handling all sorts of cases including civil, commercial and labour cases. Second, the Federal Ethics and Anti-Corruption Commission used to prosecute criminal cases and in 2001 E.C. (July 2008/June 2009) its annual budget was Birr $19,206,000$. One can make a judgement based on the numbers appearing here.

${ }^{13}$ Federal Police Proc No 720/2011, art 6(1), (4). In addition to the general investigative responsibility of the Federal Police Commission on crimes falling under the jurisdiction of the federal courts, it is given specific jurisdiction for prevention and investigation of crimes that are listed under art 6(5), such as, counterfeit of currencies and payment documents, crimes relating to computers and information networks, and human trafficking and terrorism. 
therefore, organised into six investigation departments. ${ }^{14}$ Likewise, the Addis Ababa Police has the same responsibilities. Thus, at the Headquarters, it also conducts investigation of crimes in five investigation departments each of which have three divisions under them working on operations, collection of evidence, and archives. ${ }^{15}$

In order to help discharge its crime prevention and investigation responsibilities better, the Police has the responsibilities to "conduct studies" and to standardise police service in the country. ${ }^{16}$ Most importantly, it has the responsibility to "collect, analyze(sic) and disseminate to the concerned organs countrywide information on causes of crimes and traffic accidents;" 17 The Federal Police did not have criminal statistics prior to 2006 Ethiopian calendar, and the statistics collected since 2006 E.C., are kept confidential to date. ${ }^{18}$ The Addis Ababa City Police does not collect criminal statistics at the Headquarters. Such data are said to be collected at branches in each sub-city; and community policing centres conduct investigation on all other sorts of crimes reported to them. ${ }^{19}$ As it is not collected and analysed at the Headquarters, such data is of no use. The police also have the power to maintain central criminal record, which is also used to provide certificate of no criminal record for individuals. ${ }^{20}$

The Federal Attorney General ${ }^{21}$ - The Federal Attorney General, representing the Federal Government, "institutes criminal ... charges" against alleged

${ }^{14}$ Those departments are investigating (a) crime of terrorism, (b) financial crimes, (c) tax and customs crimes, (d) crimes relating to trademark, (e) corruption crimes, and (f) other crimes falling under the federal courts, such as, human trafficking. One can see that on many of them there are special penal legislation or administrative legislation containing penal provisions. Thus, the departments appear to be organized along a certain legislation. Interview with Inspector Melkamu Mussie, Federal Police, on April 4, 2018.

${ }^{15}$ The departments at the Headquarter are investigating crimes of: (a) robbery; (b) homicide; (c) consumer protection and tax; (d) corruption crimes; and (e) miscellaneous. Interview with Tsegaye Balacha, Addis Ababa Police, Investigation Division Head on April 10, 2018.

${ }^{16}$ Federal Police Proc No 720/2011, art 6(20).

${ }^{17}$ Id., art 6(23). Under the repealed Federal Police Commission Proclamation, No 313/2003, art 7(12), the Federal Police Commission had the same responsibility to "collect and analyse criminal data and statistics ...countrywide" which is more accurate description of the responsibility.

${ }^{18}$ Melkamu Mussie, supra note 14.

${ }^{19}$ Tsegaye Balacha, supra note 15.

${ }^{20}$ Federal Police Proc No 720/2011, art 6(14).

${ }^{21}$ The powers and responsibilities of the former Ministry of Justice (Proclamation No 916/2015) are transferred to the Federal Attorney General office. Federal Attorney General Establishment Proclamation No 943/2016, (“Attorney General Proclamation") art 22. 
offenders. ${ }^{22}$ Unique to its position, the Federal Attorney General Office is the "principal advisor and representative of the Federal Government" on legal matters. ${ }^{23}$ As such, it has the responsibility to draw bills "to be promulgated by the Federal Government; ensure that draft laws prepared by government organs are consistent with the Constitution and federal laws." 24 In order to discharge its responsibilities better, it has the responsibility to "undertake legal reform studies." ${ }^{25}$ It further has the responsibility to "establish, and enforce a system that enables the collection, organization, analysis and dissemination of criminal justice information." 26

The Courts - The President of the Federal Supreme Court has the responsibilities to "prepare and submit to the House of Peoples' Representatives the work plan and budget of Federal Courts and implement same upon approval, forward his opinion on requests for budgetary subsidy to regional courts exercising federal jurisdiction by delegation. ${ }^{, 27} \mathrm{He}$ also has the responsibility to "cause the preparation of the statement regarding the activities of the Federal Courts and the submission of reports on the activities of regional courts concerning Federal cases, as supported by statistical data." ${ }^{28}$ Finally, he shall "submit to the House of Peoples' Representatives, researched report on the judicial activities of the Federal Courts." 29

Likewise, the presidents of the Federal High and Federal First Instance Courts have the responsibility to "cause the preparation of statements, supported by statistical data, regarding the activities of the Court." ${ }^{30}$ They submit their reports to the Supreme Court President to make it a part of his report to the House of Peoples' Representatives. These reports and statistical data obviously include the criminal cases filed in the courts, cases disposed during the year, case load and case congestion.

The data collected by the court are incidental to opening of new case files; they are not collected in usable format. Such data are not properly tabulated, analysed and interpreted for other purposes. Therefore, the data were never used

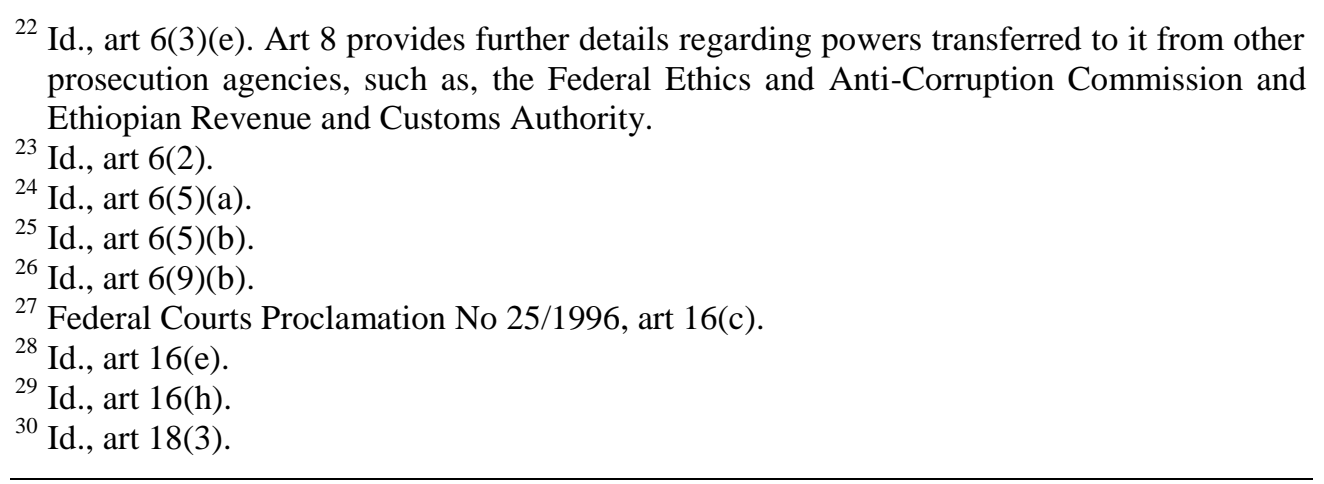


for reporting; the reports presented to the House of Peoples' Representative are only qualitatively described. ${ }^{31}$

\subsection{The types and manners of data collection}

The proclamations which require data to be collected, analysed and presented do not provide for the nature of the statistical data to be collected. The data collection is not a separate responsibility; it is associated with the responsibilities of the respective institutions. The collection and analysis of the data may depend on the purpose for which they are required. The police are required to compile data regarding the "causes of crime and traffic accident." The Federal Attorney General is required to collect data regarding the "criminal justice information." The court is required to collect data on cases appearing before such court "supported by statistical data". Therefore, the types of data required to be collected depends on the nature of the responsibilities of the respective institutions.

For instance, the three principal responsibilities of the police are crime prevention, investigation and maintaining criminal record. Therefore, the data to be collected need to be related to the activities undertaken by the police. Because the data at the Federal Police is said to be confidential, we cannot discuss the patterns of such data collection and tabulation. However, in an ideal situation, it needs to show the number of complaints individuals filed before the police, the number of cases that merited investigation, those cases referred to the public prosecutor, the number of cases that required further investigation, and the number of cases that resulted in conviction. The final data need to be classified based on the nature of the crime.

Likewise, the Attorney General's report is required to state the number of cases that are closed by the public prosecutor at the investigation stage. The report should also indicate the number of cases that were closed by the public prosecutor for various reasons, such as, lack of evidence, lapse of period of limitation, for public interest reason. Moreover, the report should state the number of cases that resulted in conviction and acquittal.

It is only after 2002 E.C. (i.e. 2009/2010) that the different branches of the Federal Attorney General's office started sending their monthly report to the Headquarters. At the Headquarters, quarterly report is compiled and it is presented at the national attorney generals' meetings held three times a year. ${ }^{32}$

${ }^{31}$ Interview with Berihu Tewoldebirhan, former Vice-President of the Federal High Court on April 21, 2018.

${ }^{32}$ Interview with BelayhunYirga, Director of the Legislative Research and Drafting Directorate at the Federal Attorney General's Office on April 22, 2018. At such meeting the States' Attorney Generals (Heads of Justice Bureaus) also present their own reports. 
This information is only used for the purposes of administrative decisions and internal prosecution policy decisions. To date, the Federal Attorney General has never used empirical data justifying legislative actions. ${ }^{33}$

The responsibilities of the court are hearing and disposing criminal cases. As such, the data that are amenable to the court are the number of cases filed before the court, the number of cases disposed by the court, and the number of cases that could not be completed. Ideally, the data would be coded and classified to put them into usable format making analysis and interpretation possible. This would give good picture, based on the type of such case, regarding how long a given case takes to completion, the number of cases that were overlaid to the following year, i.e., the rate of case congestion.

The police, Federal Attorney General and courts may use the data for administration of their regular business, in order to allocate human and material resources. Such different responsibilities of those institutions may give the impression that the data to be collected by the respective institutions are different. However, looking at the criminal justice administration as 'a system' working in coherence, they refer to the same thing at different stages of the administration of justice. The Attorney General, as the legal advisor of the Federal Government, may use such information for legislative action. Therefore, the ultimate use of the data is for policy and legislative action, which ultimately defines the cross-cutting nature of the data. ${ }^{34}$

\section{Use of Criminal Statistics by Those Institutions}

The criminal statistics is used for various types of decision making. In the normal discharge of the responsibilities of those institutions, they may be used as a basis for administrative decisions in the court, in the prosecution office and in the police, in the allocation of human and material resources. These data are ultimately used as justification for public policy decision and legislative action.

\subsection{Police use of criminal statistics}

It is based on such data that the police deploy forces both for crime prevention and crime investigation activities. For instance, if one of the departments such as

Further, the Federal Attorney General intends to introduce National Integrated Justice Information System (NIJIS). This information gathering procedure is said to give the Attorney General national overview of events from the States' Woreda Courts to the Federal Supreme Court.

${ }^{33}$ Ibid.

${ }^{34}$ Some attempt to make distinction between criminal and judicial statistics; but they ultimately mean the same thing. H. Taylor (1998) "Rationing Crime: The Political Economy of Criminal Statistics Since the 1850s" in 51 Economic History Review, No 3, at 580,581 . 
the department investigating robbery is overstretched because the crime of robbery is said to have increased, the police may allocate its force on the prevention and investigation of the crime of robbery. If the human and material resources are lacking in such department, other members may be transferred to such robber yinvestigation department from other departments not so overstretched. Suppose the number of crimes reported in other departments, such as, trademark related crimes are less frequent, the staff in this department may be transferred to those overstretched departments. The police have a relatively good information regarding the rise and the decline of crime rate at a particular moment. This information is used for decisions within the institution; but it can also be used for criminal legislative reform too.

The Federal Police has participated in (initiated) two major special penal legislations, the Anti-Terrorism Proclamation and Money Laundering and Financing of Terrorism. ${ }^{35}$ Even though the contents and findings of the research were not presented to the lawmaker, the records show that the Proclamation adopted to control vagrancy was adopted based on the research that is said to have been undertaken by the Federal Police. ${ }^{36}$ These researches could not rely on criminal statistical data because there was no such data at the time of the adoption of the Proclamations. Yet, even if the Federal Police had them, it does not have to be the drafter of the bill for that tends to create a literal police state; such data may rather be used by other agencies, such as, the Federal Attorney General.

\subsection{Use of criminal statistics by the courts}

The police identifies, investigates and reports a possible commission of crime. Complaints which do not presumably show commission of crime would not worth investigation. In fact, complaints which are initially identified as possible commission of crime might not continue if the evidence shows that there was no crime in the first place.

\footnotetext{
${ }^{35}$ The minutes of public hearing on the Anti-Terrorism draft Bill, show that the head of the Federal Police is one of the resource persons who appeared before the Security Affaires Standing Committee along with National Security Agency. (See, 'A Brief Minutes of Public Hearing with Stakeholders on the Anti-Terrorism Bill Organised by Justice and Administration Affairs and Foreign, Defence and Security Standing Committees' (June 24, 2009, in Amharic, at 3). Likewise, the Minutes of the Public Hearing on Draft Bill on Money Laundering and Financing of Terrorism Proclamation indicate that the Federal Police is also a resource person. One can certainly see that the police leads such the criminal law drafting process. Particularly in legislative process like ours -where the legislative debate is non-existent- it is not a healthy lawmaking process.

36 'Explanatory Memorandum on the Draft Vagrancy Control Proclamation' (in Amharic), at 1.
} 
The court serves the public by allocating benches, judges and support staff. Because of the nature of independence of the judiciary, the administration can only support the judges in administrative matters to help them discharge their constitutional duties competently and independently. The number of judges appointed may be determined depending on the steady increase of the cases filed in the courts. In some instances, the legislation specifically requires a special bench, such as, the tax laws. ${ }^{37}$ However, as statistical data are not tabulated and analysed to be used to make administrative or policy decisions regarding the number of benches and judges for specific categories of cases, all decisions were normative. ${ }^{38}$

\subsection{Use of criminal statistics by the Federal Attorney General}

In an ideal situation, the crime investigation arm of the police and the prosecution office work in close collaboration. Thus, the prosecution has the information the police has. This would enable the prosecution office to help the police in investigation and other activities. However, it can also take its own measure in terms of the allocation of human and material resources, focus of the prosecutorial action, and prosecutorial policy decisions. Further, data, such as, prior convictions of defendants are found in the police which helps the prosecutors to lead the prosecution.

The most important use of criminal data is in legislative reform. Ethiopia has decentralised legislative drafting that any agency can submit draft bill to the House of Peoples' Representatives. ${ }^{39}$ However, there is a desire to have a centralised draft review system. Therefore, as advisor of the Federal Government on legal matters, the Attorney General itself draws up bills; but it also reviews bills drawn up by other agencies. ${ }^{40}$ It is here that the national criminal statistical data are relevant.

\subsection{Legislative use of criminal statistics - Principled action and duties of power}

The criminal law is the most intrusive state action; as such, legitimacy of the criminal law is a subject that needs to be addressed carefully. Wintgens argues

${ }^{37}$ The Ethiopian Revenue and Customs Authority Establishment Proclamation, No 587/2008, art 17.

${ }^{38}$ Berihu Tewoldebirhan, supra note 31.

${ }^{39}$ See supra note 2.

${ }^{40}$ The Council of Ministers Working Directive, art 42(1)(c), (5)(b) provides that, as the legal advisor of the Federal Government, the Ministry of Justice must be consulted and where new crimes are created or punishments are revised, the Ministry of Justice must be consulted for propriety and conformity with the Penal Code. In the Attorney General Proclamation art 6(5)(a), it is given the power to maintain (universal) coherence of the draft bills drawn up by other agencies. 
that legislative action in general and attached sanction in particular should be principled actions which are founded on individual freedom. ${ }^{41} \mathrm{He}$ argues that freedom is the principium; thus, any rule has to continuously justify its existence. In order to justify the existence of a rule (a criminal norm), it is necessary to comply not only with the formal requirements of the lawmaking process, but also with those basic principles. ${ }^{42}$ Those principles are "concretisations of freedom as principium." The first and the most important principle is the principle of coherence by which he means rules need to cohere not only within the legal system but also with reality. ${ }^{44}$ The second principle is the principle of alternativity which refers to an external limitation to freedom is legitimate provided there is no alternative measure to address the failing social interaction. ${ }^{45}$ The third principle is the principle of temporality. ${ }^{46}$ And finally, there is the principle of normative density. ${ }^{47}$

In order to comply with those principles, the legislature has duties to comply with. In making legislations, the lawmaker needs to have both normative and empirical justifications. ${ }^{48}$ Normative justifications are doctrinal justifications. Thus, for the purpose of criminalisation of a particular conduct, there has to be positive justification that the protected legal interest needs the protection of the criminal law. The negative requirement is that, the legal interest cannot be protected better (or as well) by other means, such as, administrative measures and civil actions. ${ }^{49}$ Embedded in and giving flesh to those normative justifications is empirical evidence. However, those empirical justifications are put in context of those normative justifications, and they have to be discussed that way.

Public policy is always under constant revision; criminalisation is one such public policy ${ }^{50}$ This is better seen in the notion of rationality of legislation. As an essential manifestation of rational lawmaking, the lawmaker has the duty to

${ }^{41}$ L.J. Wintgens (2012) Legisprudence: Practical Reason in Legislation, Surrey: Ashgate Publishing, at 231-282. For a concise summary, see Kristan, supra note 10, at 53.

${ }^{42}$ Wintgens (2013), supra note 1.

${ }^{43}$ Wintgens (2012), supra note 41 , at $4-6,279$.

${ }^{44}$ Id., at 35 .

${ }^{45}$ Id., at 258 .

${ }^{46}$ Id., at 267.

${ }^{47}$ Id., at 271.

${ }^{48}$ Whether the legislature has to justify its actions and whether it has to provide reasons is beyond the scope of this article. However, the principle of coherence is a binding constitutional principle. FDRE Const., arts 9(1), 13.

${ }^{49}$ See supra note 4 and 5.

${ }^{50}$ See generally, Arenas, supra note 9. 
reflect. ${ }^{51}$ This duty to reflect is more than a morality of duty but it refers to the morality of aspirations, excellence. Thus, while the constitution does not impose an obligation of quality of legislation, Wintgens invokes five requirements for assessing the rationality of legislation particularly for those legislation associated with sanction. 52

\subsubsection{Pre-legislative phase}

\section{a) A duty to establish the facts}

At the pre-legislative phase, the lawmaker undertakes various actions, in establishing the facts. ${ }^{53}$ The establishment of such facts refers to identification of the social interest to be protected, ${ }^{54}$ including contextualisation of the problem by identifying the "dysfunctional social situation" and whether it requires legislative intervention. ${ }^{55}$ It must also indicate that the measure that is identified to address the problem must rationally be linked with addressing such problem. ${ }^{56}$ The Council of Ministers Working Directive (2003), art 5(5) requires that "matters (proposals) presented for the decision of the Council shall be based on full understanding of the facts and information helping decision in favour of public interest." [translation mine]. Sub-art (6) further provides that "the decision-making process of the Council shall reflect all relevant matters are investigated into and policies and procedures were considered" [translation mine].

Such fact-finding is supposed to be made by the agency drawing up the bill. Thus, when the lawmaker intends to adopt the Vagrancy Control Proclamation or a tax proclamation containing penal provisions or anti-terrorism law, ideally,

${ }^{51}$ Taking the German notion of the "duty to reflect", Wintgens initially developed this theory in 2002. L.J. Wintgens (2002) "Legislation as an Object of Study of Legal Theory: Legisprudence" in L.J Wintgens (Ed.) Legisprudence: A New Theoretical Approach to Legislation (Oxford: Hart Publishing), at 32-33.

${ }^{52}$ Kristan, supra note 10 , at 55.

${ }^{53}$ Wintgens (2002), supra note 51, at 32.

${ }^{54}$ S.R. Ferrandez (2016) "Legislative Evaluation in Spain: Its Necessary Application in the Approval of Criminal Law Reform" in Martin and de Morales Romero (Eds.), supra note 5 , at 79 .

${ }_{55}^{55}$ Ibid.

${ }^{56}$ FDRE Ministry of Capacity Building, (2005) FDR Ethiopia Comprehensive Justice System Reform Program Baseline Study Report, Amsterdam: Primavera Quit.

Ethiopia commissioned a baseline research of the justice system. The result of the research indicates that there were various forms of shortcomings of the justice system. In terms of trained personnel, institutions and their facilities, the working of those institutions, etc., were lacking in many aspects. This baseline research was used for the justice system reform involving both the legislative reform, institutional reform and legal education reform. 
there are facts that are inquired into. This particularly includes facts that were said to have called for the imposition of a criminal sanction without which the problem cannot be addressed. This inquiry is in conformity with the criminalisation doctrine - that there must be a positive requirement as well as negative requirement. ${ }^{57}$

As legislation is adopted on areas where there were governing penal provisions, the explanatory memorandum should address not only the purpose of the reform but also how those existing provisions fail to address the problem that necessitated the reform. ${ }^{58}$ Contrary to these principles, however, the provisions of art 9(6) of the Council of Ministers Working Directive appears to be the most prominent. The documents presented to the Council of Ministers is presented both in Amharic and English languages and accompanied with a brief explanatory memorandum to the bill.

\section{b) A duty to balance}

Criminalisation is the most intrusive state action. Therefore, in exercising its criminalising power, the lawmaker needs to balance other values, most important of which is fundamental rights. ${ }^{59}$ However, before the state goes into balancing among the various conflicting values, ${ }^{60}$ it must select the least intrusive measure from a menu of state action, such as, administrative measures, civil action and maintaining the already existing measures. In the doctrine of criminalisation, the negative requirement is that the criminal law is used as a last resort measure, supplementing all other state measures. ${ }^{61}$ This requirement of rationality of legislation is that, the lawmaker, based on the facts presented, would evaluate the alternative measures in light of the potential coercive nature of the designed action and it arrives at such decision after thorough evaluation of those possible alternative actions. ${ }^{62}$

${ }^{57}$ See, supra notes 4 and 5.

${ }^{58}$ Ferrandez, supra note 54, at 94.

${ }^{59}$ Simeneh Kiros Assefa (2018) "Sovereignty, Legitimacy and Fundamental Rightsas Limitations to Criminalisation Power of the State" In 12 Mizan L. Rev., No 1.

${ }^{60}$ For principle theory of the bill of rights, see Id., section 5.2.

${ }^{61}$ See generally, J. Sieckmann (2016) "Rational Lawmaking, Proportionality and Balancing" in K. Meßerschmidt and A.D. Oliver-Lalana (Eds.) Rational Lawmaking under Review: Legisprudence According to the German Federal Constitutional Court(Switzerland: Springer); A.M.P. del Pino (2016) "The Proportionality Principle in a Broad Sense and Its Content of Rationality: The Principle of Subsidiarity" in Martin and de Morales Romero (Eds.), supra note 5, at 264 - 267.

${ }^{62}$ Wintgens (2002), supra note 51, at 33. 


\section{c) A duty to prospective evaluation}

When the lawmaker adopts measures, it also evaluates the likelihood of the success of the measure as well as other unwanted consequences which could reasonably be foreseen at the time of adoption of such measure. ${ }^{63}$ It should also take into consideration the social and economic, legal and institutional implications. ${ }^{64}$ The Council of Ministers Working Directive requires that if the bill introduces or modifies criminal sanctions, the Ministry of Justice shall be consulted; and if it has the effect of modifying or creating institutions, the Prime Minister shall be consulted prior to tabling the subject for discussion, and if such bill has financial consequences, the Ministry of Finance and Economic Development shall be consulted and their views form part of the report. ${ }^{65}$

The Directive further requires an express assertion that the bill does not contradict constitutional principles, including fundamental rights, and it actually conforms with the existing legal order including international obligations. ${ }^{66}$ Ferrandez refers this action as "legislative impact assessment." because the lawmaker is working under time pressure and with "bounded rationality", the possibility of not addressing the problem effectively is real. ${ }^{68}$ Therefore, the decision of the lawmaker has to be evaluated continuously to be discharged in the following two additional legislative duties. ${ }^{69}$

\section{d) A duty to take future circumstances into consideration}

The legislature is making laws to be applied prospectively. The legislative impact assessment needs to take possible future developments into consideration whether such is the result of change of circumstances or the effects of the legislation. $^{70}$ The legislature cannot humanly foresee all possible future circumstances; thus, it must expect problems that might arise at the time of the implementation of such law, which the lawmaker needs to react to.

${ }^{63}$ Id., at 33 . He further elaborated this in later researches that it is one of the difficulties the lawmaker faces that it cannot fully predict the effects of its actions because the knowledge at the time of the making of the legislation is obviously limited. Wintgens (2013), supra note 1, at $16 \mathrm{ff}$. Further on ex-ante evaluation of institutional design, see generally, J. Becerra (2016) "Institutional Redesign Proposals for the Preparation of Criminal Policy by the Government: The Focus on Ex-Ante Evaluations" in Martin and de Morales Romero (Eds.), supra note 5.

${ }^{64}$ Ferrandez, supra note 54, at 89, 90.

${ }_{65}$ Arts 42(1)(c), (5)(b), art 9(5), Art 31(7), and arts 9(4), 31(6), respectively.

${ }^{66}$ Id., arts 46(1)(a), (b).

${ }^{67}$ Ferrandez, supra note 54; Id., at 84.

${ }^{68}$ Wintgens calls such limitation in terms of skills, information and time, 'bounded rationality'. Wintgens (2013), supra note 1 , at 14, 15 .

${ }^{69}$ Wintgens (2002), supra note 51, at 33.

${ }^{70} \mathrm{Id}$., at 33 . Wintgens (2013), supra note 1 , at $16 \mathrm{ff}$. 


\subsubsection{Post-legislative phase: A duty to correct legislation at a later stage}

It is indicated that in prospectively applied law, the lawmaker cannot foresee everything. The law must be re-evaluated as it is implemented in order to see whether it has created socially and economically acceptable conditions, ${ }^{71}$ whether there are any institutional limitations to achieving its objectives, and whether it addresses the realities of its time. The law is valid not only because it complies with the formal requirements of the lawmaking, but it must also cohere to realties on the ground. ${ }^{72}$

Where there is a problem identified, the lawmaker takes the necessary corrective measures. ${ }^{73}$ Therefore, even when the other four conditions of duties were not complied with, it would be of significant to meet the last requirement; i.e., revisiting the laws retrospectively after their adoption. However weak the process may be, it is one method of enforcing the bill of rights. ${ }^{74}$ Owing to lack of effective constitutional litigation procedure and practice, and because there is no accountability, the Ethiopian lawmaker does not have incentive for such continuous revision.

\section{The Practice of Using Criminal Statistics in Legislative Decisions}

It is indicated that the legislature needs to have the criminal statistics, among others. Based on the theory of criminalisation, there has to be an identified social problem, and that social problem could not be addressed by other means but only through the criminal law. Once such initial decision is made based on experts' advise, the legislature has the duty to evaluate whether such policy decision helps achieve its intended purposes. The reason why criminal statistics is used in the evaluation of public policy is that, several of those penal legislation or penal provisions contained in administrative regulations were already in place and they are tested over a certain period.

For instance, by the time the Vagrancy Control Proclamation was adopted, vagrancy was criminalised for several decades already and was governed by art 471 of the 1957 Penal Code. Thus, when the Proclamation states as its motive that "vagrancy [had been] increasing and widespread in our country from time to time" and it had become "a threat to public tranquillity and order of the

\footnotetext{
${ }^{71}$ Ferrandez, supra note 54, at 87.

${ }^{72}$ Wintgens (2013), supra note 1.

${ }^{73}$ Wintgens (2002), supra note 51, at 33. Arenas, supra note 9, at 13, 20.

${ }^{74}$ See generally, A.D. Oliver-Lalana (2016) "Due Post-Legislative Process? One the Lawmakers' Constitutional Duties of Monitoring and Revision" in Meßerschmidt and Oliver-Lalana (Eds.), supra note 61.
} 
people" and that the Proclamation had been adopted with a view to "dispel this threat," it must first show how the existing criminal norm failed to achieve that purpose. $^{75}$ This can be shown principally through criminal statistics; however, there is no criminal statistics presented to the lawmaker that the provisions contained in the Penal Code failed to accommodate. The bill was drawn by the then Ministry of Justice and Ministry of Federal Affairs and it did not present any such evidence to parliament. ${ }^{76}$

Likewise, regarding the criminalisation of engaging in commercial activities without a valid license, the Proclamation regulating commercial registration was adopted without a background study of the problem and justification. However, the Commercial Registration Proclamation No 67/1997 had criminalized engaging in commercial activities without a valid license. It was made punishable with imprisonment from three to five years and fine twice the profit the person is said to have earned in such period, in addition to administrative measures the Ministry of Trade or any other appropriate organ would take.

This Legislation was substituted with Commercial Registration Proclamation No 686/2010. The criminal punishment was increased significantly. Again, there is no statistical evidence that shows the criminal punishment imposed as per Proclamation No 67/1997 failed to help achieve the objectives of the said Proclamation. Yet, while this Legislation was revised in 2016, the punishment for such conducts are maintained as they were in the 2010 Proclamation and other conducts were criminalised too on pretext of 'clarification' of provisions. ${ }^{77}$

\subsection{Vagrancy and Vagrancy Control Proclamation}

The Vagrancy Control Proclamation No 384/2004 was adopted while there was a provision in the Penal Code punishing vagrancy, art $471 .{ }^{78}$ The preamble states increase in vagrancy crime as a justification for adopting the Proclamation. The bill was said to be drawn up in response to the inadequacy of art 471 to address the growing problem. The travaux préparatoires indicates

\footnotetext{
${ }^{75}$ Kristan, supra note 10 , at 55.

${ }^{76}$ See Explanatory Memorandum, supra note 36; 'Minutes of Public Hearing Organised by Law and Administrative, and Social Affairs Standing Committees on the Draft Bill to Control Dangerous Vagrancy' (January 12, 2004, in Amharic).

77 'Explanatory Memorandum on Commercial Registration and Business Licence Draft Bill' (in Amharic), at 2. 'Minutes of the Public Hearing Organised by the House of Peoples' Representatives Commercial Affairs Standing Committee on the Commercial Registration and Business License Draft Bill' (July 5, 2016, in Amharic). Also see section 4.4, infra.

${ }^{78}$ Art 471(1) provides that "[w]hosoever, having no fixed abode or occupation and no regular or visible means of support, and being able-bodied, habitually and of set purpose leads a life of vagrancy or disorderly behaviour, or lives by his wits or by mendicancy, refusing to take honest, paid work which he is capable of doing, thereby constituting a threat to law and order, ..."
} 
that, a research conducted by the Federal Police indicated that vagrants with repeated criminal records are increasing in number from time to time in major cities threatening the peace and tranquillity of the public. ${ }^{79}$ The reasons for the inadequacy were said to be of two types. The first relates to the vagueness and/or narrowness of the provisions of art 471 . The second relates to the lack of procedural guarantees that made the provisions of art 471 ineffective. ${ }^{80}$ Thus, the law was drafted in such a manner that a list of conducts said to be conducts of vagrancy are provided for with severe punishment, and the crime is made non-bailable. ${ }^{81}$

The reasons provided, both in the preparatory work as well as at the public hearing, were insufficient and contradictory. ${ }^{82}$ However, despite the claim of prior research by the Federal Police, the nature and content of such research was not made known. Having regard to the fact that the Federal Police did not keep criminal statistics prior to 2006 E.C. (i.e. 2013/2014), it is certain, if there was any background research, it would not deal with criminal statistics.

At the public hearing, there were two significant challenges to the bill from two participants. One participant commented focusing on the merit of the draft bill that, it makes vagrancy a matter of status and ends up to be discriminatory contrary to the constitutional provisions, and denying bail for vagrancy is a matter of concern which is evident for any ordinary lawyer. ${ }^{83}$

The other participant's comment focused on the motives of the bill; he stated that it is meant to silence opposition. ${ }^{84}$ The preparatory work makes reference to the incidents that took place in $2001^{85}$ relating to the protests of Addis Ababa University students regarding the conditions on campus and demanding academic freedom. ${ }^{86}$ They had discussion with the Minister of Education

79 'Explanatory Memorandum', supra note 36, at 1. Please note that while the preamble of the Proclamation states the increase in vagrancy crime, the Explanatory Memorandum states about the increase in number of vagrants in major cities.

${ }^{80}$ Id., at 12

${ }^{81}$ Vagrancy Control Proclamation, arts 4, and 6(3), respectively.

${ }^{82}$ It is lamented that because of the difficulty of proving each element constituting the crime of vagrancy as provided for under art 471 of the Penal Code, it had been difficult to secure conviction; because the courtused togrant bail to such suspected vagrantsroutinely, the police had find it difficult to complete the investigation, to secure their attendance in court and vast majority of them were discharged or acquitted. Explanatory Memorandum, supra note 36 , at 12 .

${ }^{83}$ Minutes of Public Hearing, supra note 76, at 10, 11.

${ }^{84}$ Id., at $12,13$.

${ }^{85}$ Explanatory Memorandum, supra note 36, at 1, 4, 12.

${ }^{86}$ The House of Peoples' Representatives constituted an inquiry commission in order to properly address the demands of the students. ENA 'Students' Demands Discussed by 
regarding their claims which 'failed'. ${ }^{87}$ The protest spread to the major high schools in the City for which the Federal Police was ill-prepared. As a result, at least 31 people were killed and several hundreds of people were wounded, ${ }^{88}$ and significant damage to property occurred. ${ }^{89}$

The Federal Government, the Ministry of Education and the Federal Police, each issued a separate press release 'advising' students and the general public to calm. $^{90}$ Each of those press releases alleged that the incident was incited by opposition political parties and human rights NGOs. ${ }^{91}$ The victims who died at the incident were portrayed by the police as vagrants with prior criminal records. ${ }^{92}$ The bill was tabled in parliament in less than three years and was shadowed by those events. ${ }^{93}$ The Ministry of Justice had taken part in the preparation process of this special penal legislation. The principal actor was the Ministry of Federal Affairs. ${ }^{94}$

\subsection{Crimes of terrorism and the Anti-Terrorism Proclamation}

The Anti-Terrorism Proclamation No 652/2009 is a special penal legislation. It criminalises certain conducts the content of some of which is clear, while the rest is not quite so. The Proclamation also provides for procedural and

Standing Committees of the House of Peoples' Representatives' Addis Zemen, Addis Ababa, May 3, 2001 (in Amharic), at 1, 7. ENA 'Inquiry Begins into the Causes of Unrest and of Damage Associated to Students' Demands' Addis Zemen, Addis Ababa, May 6, 2001 (in Amharic), at 1, 6.

${ }^{87}$ ENA 'The Meeting between Addis Ababa University Students and the Minister of Education Ended without Agreement', Addis Zemen, Addis Ababa, April 12, 2001 (in Amharic), at 1, 5 .

${ }^{88}$ ENA 'Police Announces 31 People Died Following Students' Protest' Addis Zemen, Addis Ababa, April 24, 2001 (in Amharic), at 1, 5.

89 ,Ethiopian Telecommunication Corporation Reported Property Worth 50 Million Birr Damaged', Addis Zemen, Addis Ababa, April 21, 2001 (in Amharic), at 1, 5.

90 'Press Statement and Resolution from the Ministry of Education' Addis Zemen, Addis Ababa, April 17, 2001 (in Amharic), at 1. 'Press Statement from the Federal Police Crime Prevention Department', Ibid.

${ }^{91}$ Ibid. The Federal Government Press Statement makes explicit reference to, more than once, All Amhara Peoples' Organisation and Ethiopian Democratic Party, from political parties and Ethiopian Human Rights Council from NGOs. Just a few days earlier, on April 8, 2001, Prof. Mesfin Woldemariam, Prof. Andargachew Tesfaye and Dr. Birhanu Nega 'participated' in a students'meeting at the National Lottery hall, for which both Prof. Mesfin and Dr. Birhanu were criminally charged. ENA 'Police Announces...' supra note 88 , at 5 .

${ }^{92}$ Id., at 1,5 .

93 'Explanatory Memorandum', supra note 36, at 12.

94 'Report and Recommendation of the Legal and Administrative Standing Committee and Social Affairs Standing Committee on the Vagrancy Control Draft Bill' (January 21, 2004, in Amharic), at 1. 
evidentiary matters. The reasons for adoption of such legislation are indicated in the travaux préparatoires, and inter alia, states that "there is no separate law governing such heinous crime" as terrorism. ${ }^{95}$ It also states that the laws in force "do not carry appropriate and proportional punishment" for such particularly heinous crime as terrorism. ${ }^{96}$

Even though the degree of participation cannot be ascertained from the parliamentary records, the Federal Police took part in the development of the Anti-Terrorism Proclamation. The other participant in drawing up the bill is the National Intelligence and Security Services. ${ }^{97}$ Yet, at the public hearing, it had been stated that between 1985 and 1998 E.C. (1992 to 2004/2005), there were various "terrorist accidents" said to have been committed, ${ }^{98}$ and there was no data presented at such hearing, nor was there a report showing how the then existing legal framework failed to address those crimes of terrorism. Leaving aside the propriety of the participation of the police in drawing up a special penal legislation bill, and having regard to its responsibilities of collection of criminal statistics, the failure of the Federal Police ${ }^{99}$ in producing data that are said to have necessitated the bill is inexcusable.

The demand for criminal statistics is even dire based on the fact that the State was refusing to adopt anti-terrorism law on the ground that the law then in force was sufficient to deal with acts of terrorism. ${ }^{100}$ In fact, there were criminal charges against individuals containing the word 'terrorism' for which defendants were convicted. ${ }^{101}$

\subsection{Tax related crimes}

It is indicated that there were provisions in the Penal Code and in the Criminal Code which punish conducts that are related to tax, that are referred to as tax

\footnotetext{
95 'Brief Explanatory Memorandum on the Draft Anti-Terrorism Bill' (in Amharic), at 10.

96 'Minutes of Public Hearing with Stakeholders', supra note 35, at 10.

${ }^{97}$ Id., at 3. The Explanatory Memorandum bear the stamp of the National Intelligence and Security Services; at the Committee hearing, the PM's Chief of Staff and the Federal Police Commissioner and representatives of National Intelligence and Security Services and Ministry of Federal Affairs were present, as resource persons to explain the bill.

${ }^{98}$ Ibid. 'Minutes of Public Hearing with Stakeholders', supra note 35, at 10

${ }^{99}$ See supra note 17.

${ }^{100}$ See Wondwossen Demissie Kassa(2013) "Examining Some of the Raisons d'etre for the Ethiopian Anti-Terrorism Law"in 7 Mizan L. Rev., No 1.

${ }^{101}$ See for instance, Public Prosecutor v Zaid Ahmed Oumer (Federal High Court, File No 01178, June 4, 2004); Public Prosecutorv Beyan Ahmed, et. al.,(Federal High Court, File No 3139, October 15, 2004); Public Prosecutor v Mohammed Abdella (Federal High Court, File No 1137, June 15, 2004); Public Prosecutor v Ahmed Nour (Federal High Court, File No 1121, March 26, 2004). In those cases, the charges for conducts of terrorism were based on the provisions of art 252(1)(a) of the 1957 Penal Code.
} 
crimes. However, the Ministry of Finance and Economic Development (MoFED) drafted tax legislation containing penal provisions totally disregarding the penal provision in the Penal Code. ${ }^{102}$

The records of parliamentary hearing do not show any substantive discussion on the content of the penal provisions. The manner of inclusion of penal provisions into the Value Added Tax Proclamation (VAT Proclamation) is problematic. The Income Tax Proclamation was drawn up with its penal provisions. ${ }^{103}$ The records of the proceedings do not show any discussion on the penal provisions. However, the records of the hearings on the VAT Proclamation indicate that, the penal provision were not initially included in the VAT Proclamation because the Penal Code provisions were deemed sufficient. However, on the recommendation of the experts (from MoFED), the House Standing Committees decided to incorporate the penal provisions in the Income Tax Proclamation into the VAT Proclamation. ${ }^{104}$ The revision was not based on criminal statistics or the lack of it. The parliamentary hearing does not mention any of those criminal statistics. The inclusion of those penal provisions could rather be called arbitrary.

\subsection{Engaging in commercial activities without a valid licence}

\subsubsection{Proclamation No 294/1971}

The first legislation that criminalized engaging in commercial activities without license for a commercial activity was the Domestic Trade Proclamation enacted in 1971. It applied on persons whose capital is more than birr 1000, and who operate without a valid domestic trade licence. The punishment was a fine up to one thousand birr or imprisonment not exceeding two months or both. ${ }^{105}$ The Penal Code only punished engagement in few professional services, such as, medical services, without proof of competence or license. ${ }^{106}$

\subsubsection{Proclamation No 67/1997}

Engaging in ordinary commercial activities without a license is made a criminal conduct under Proclamation No 67/1997, as part of the trade regime reform.

${ }^{102}$ See for instance, Value Added Tax Proclamation No 285/2002, Income Tax Proclamation No 286/2002, Excise Tax Proclamation No 307/2002, and Turn Over Tax Proclamation No 308/2002.

103 'A Brief Explanatory Memorandum on Income Tax Draft Bill' (in Amharic), at 2, 9. There is no mention of criminal responsibilities in other documents submitted to the House, such as, documents addressing major legal issues, forming part of the technical document.

104 'Amendments to the Draft Bill on Value Added Tax', at 1, 2.

105 The Domestic Trade Proclamation, 1971, art 3(3) and 15(1). Note that the exchange rate was 1 Birr $=1$ USD.

${ }^{106}$ Pen Code, art 518(1), (2). 
Thus, a person who engages in commercial activities without having a valid license shall be punished with fine equal to double the revenue he earned, and with imprisonment from 3 to 5 years. ${ }^{107}$ Obtaining a business license or renewing a license based on false documents is punishable with imprisonment from 7 to 10 years. ${ }^{108}$ Moreover, violation of other provision of the Proclamation, or the Regulations or a public notice issued under the Proclamation is punishable with "fine from Birr 3,000 to 5,000, ... and with imprisonment from 6 months to 1 year." ${ }^{109}$ It was further provided that if there is other severe penalty, that other penalty would be imposed, and this criminal punishment is imposed despite administrative measures. The travaux préparatoires depicts the desire to impose "severe" criminal penalty. ${ }^{110}$

Taking lesson from the 1971 Proclamation, the Federal Government Commercial Registration and Business Licensing Council of Ministers Regulations No. 13/1997, arts 21 and 22 provided that persons who are required to get registration certificate are those with capital of Birr 5,000 and above. The reason for requiring registration was the need for information for the Government. ${ }^{111}$ Moreover, renewals are required in order to ensure that competence certificates are still valid, and to create conducive conditions for collection of government revenue because tax clearance is necessary to have the license renewed, and to gather relevant information. ${ }^{112}$

\subsubsection{Proclamation No 686/2010}

Proclamation No 67/1997 was substituted with Commercial Registration and Business Licensing Proclamation No 686/2010. The conducts criminalised in the previous legislation remain criminalised in this Proclamation too. However, the punishments are significantly increased. Thus, engaging in commercial activities without a valid licence is punishable with rigorous imprisonment from 7 to 15 years, fine from Birr 150,000 to 300,000 and confiscation of production or delivery equipment. ${ }^{13}$ Obtaining a commercial registration or license or renewing same on false document is punishable with rigorous imprisonment

\footnotetext{
${ }^{107}$ Commercial Registration and Business Licensing Proclamation No 67/1997, art 46(1).

${ }^{108}$ Id., art 46(2).

${ }^{109}$ Id., art 46(3).

110 'Minutes of Public Hearing Organised by Economic Affairs Standing Committee' (February 24, 1997, in Amharic), at 2. The parliamentary hearing records show that all the authorities and resource persons present to explain the contents of the draft bill were from the Ministry of Trade and Industry, and a representative from the Ministry of Justice was mentioned (except, he failed to attend the hearing).

${ }^{111}$ Id., at 6, 9.

112 Ibid.

${ }^{113}$ Commercial Registration and Business Licensing Proclamation No 686/2010, art 60(1).
} 
from 7 to 12 years and fine from Birr 60,000 to $120,000 .{ }^{114}$ Likewise, violation of other provisions of the Proclamation, regulation or public notices that may be issued pursuant to the Proclamation may be subject to rigorous imprisonment from 3 to 5 years and fine from Birr 30,000 to 60,000. ${ }^{115}$

The travaux préparatoires states that a study was conducted between 2001/2002 and 2009/2010. And the bill was drawn based on such study and the Industrial Development Strategy. Further, the objective for the revision on renewal of commercial license is strongly linked with tax payment, because tax clearance is necessary for renewal. ${ }^{116}$ However, there is no data or criminal statistics presented in support of the increased sentence. In fact, the travaux préparatoires makes a passing remark in one sentence that "leaving aside the conducive conditions created by the draft bill, appropriate penal provisions are included for fine and imprisonment of those who unlawfully register or renew their license" [translation mine]. ${ }^{117}$

At the public hearing organised by the HoPR Trade and Industry Affairs Standing Committee, there were serious objections to the criminal provisions both from the Members of Parliament and representatives of Addis Ababa Chamber of Commerce. The objections include, (a) the penal provisions were said to be borrowed from other countries; however, the maximum penalty in those countries is said to be imprisonment for two years; often, such actions in those countries from which we drew experience are subject to fine and administrative measures; ${ }^{118}$ (b) the bill prefers a graver penalty if it is provided for in other legislation which is contrary to the provisions of the FDRE Constitution art 22(2), which prefers the lesser penalty; ${ }^{119}$ (c) the minimum fine, i.e., Birr 150,000, for commercial activities without licence is unreasonable because the person may have much less amount of capital; ${ }^{120}$ (d) it would be utterly impractical to impose a fine not less than Birr 150,000 while we, at the same time, send such person to jail, a circumstance in which such person would not be able to even provide for his family; ${ }^{121}$ (e) the criminal responsibilities are also for violations of directives which are not published in the Negarit Gazeta. ${ }^{122}$

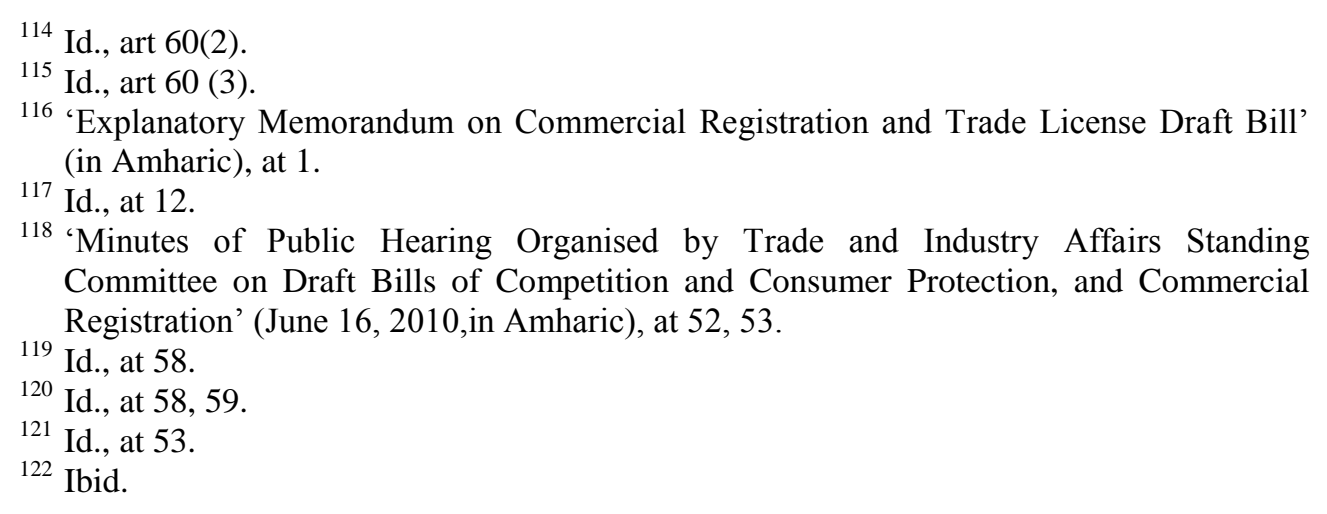


According to the response from the State Minister:

- the previous Proclamation did not help the Government achieve its ends and "unlawfulness grew rampant". ${ }^{123}$

- The criminal penalties in that Proclamation are "inconsiderable fine and imprisonment". 124

- This legislation is drafted because "unlawfulness has become so common the Government has to make use of all its power to conduct control, to support those operating within the legal framework to help them become successful, and impose the appropriate punishment on those who chose the unlawful conduct in commerce." 125 [translation mine].

The State Minister further equated engaging in commerce without a valid license with contraband, whose punishment is imprisonment for 7 to 15 years. ${ }^{126}$ The legal advisor of the Ministry indicated that directives are essential for the administrative and regulatory work; thus, the Ministry does its best to have those directives published in newspapers. He, thus, gave the impression that their being not published in the Negarit Gazeta is 'not a problem'. ${ }^{127}$ The records show after such discussion, the Committee, with few minor editorial changes, recommended to the House that the bill be enacted as law.

\subsubsection{Proclamation No 980/2016}

The Ministry of Trade believes that Proclamation No 686/2010 had made fundamental changes in the realms of commerce. It was amended several times but after having been tested for more than five years, it was further replaced with Proclamation No 980/2016. The factor stated as reason for the revision was "clarifying" several subject matters, including the penal provisions. ${ }^{128}$

Regarding the penal provision, it is stated in the travaux préparatoires that the penal provisions are short and every penal matter was crammed into those short provisions; and it was found necessary to clarify those general statements of the

${ }^{123}$ Id., at 47.

${ }^{124}$ Id., at 61 . Please note that when they were initially adopted, those criminal penalties were referred to as 'severe'. See supra note 110.

${ }^{125}$ Id., at 61,62 .

${ }^{126}$ Id., at 26,27 . It is needless to state that contraband is classical crime involving illegal crossing of national border importing or exporting prohibited, or restricted goods or without paying the necessary duties; doing business without a valid license had never been a crime until recently for those with least threshold capital. Yet, trading without a valid license also carries administrative measures, fine and confiscation of production materials.

${ }^{127}$ Id., at 65.

${ }^{128}$ Explanatory Memorandum, supra note 77, at 2. 
penal provisions. ${ }^{129}$ In Proclamation No 686/2010, the criminal conducts were engaging in business activities without a valid license, obtaining or renewing a trade license based on false documents and violation of other provision of the Proclamation or of Regulations and Directives to be adopted based on the Proclamation. These are conducts that continued to be criminalised under art 49(2), (3) and (8), respectively, of Proclamation No 980/2016. The facts constituting the crimes and the punishments are not changed.

Sub-art (1) of art 49 of Proclamation No 980/2016 punishes the preparation or use of "false certificate of commercial registration, business license or special certificate of commercial representation .... with fine from birr 150,000...to Birr $300,000 \ldots$ and with rigorous imprisonment from $7 \ldots$ to $15 \ldots$ years." The conducts criminalised in this provision were not covered by the provisions of the previous Proclamation that it can hardly be said "clarification".

The contents of sub-arts (4), (5), (6) and (7) are obviously new. Sub-art (4) punishes transferring "business licence to third party by way of sale, lease, donation or in a similar fashion" with fine from Birr 50,000 to Birr 100,000 and rigorous imprisonment from 5 to 10 years. However, if the transfer was made to a foreign national, the punishment would be fine from birr 200,000 to 300,000 and rigorous imprisonment from 7 to 15 years. This conduct had always been a legitimate business practice. When such conduct is criminalised under the disguise of 'clarification' of the penal provisions, the Ministry of Trade did not give any reason both in the travaux préparatoires and at the public hearing. It is stated that regulation of transfer of license is good tool for the tax system. ${ }^{130}$ It is also indicated that diaspora Ethiopians are taking advantage of another individual's license. ${ }^{131}$ However, there is no evidence offered by the experts. ${ }^{132}$

Sub-art (5) punishes failing to notify change of address to the registering office within a period to be specified in the regulations with fine from Birr 5,000 to 10,000 and with simple imprisonment not exceeding three months. Likewise, sub-art (6) punishes failing to notify the registering office within 30 days of

${ }^{129}$ Id., at 3, 6 .

${ }^{130}$ Minutes of the Public Hearing, supra note 77, at 10.

${ }^{131}$ Ibid.

${ }^{132}$ Setting aside the justifiability criminalization of such conduct, there appears to be two reasons for this provision. There are business areas restricted only to Ethiopian nationals. However, the Ethiopian diaspora is engaging in this commercial activity restricted to Ethiopians only by leasing trade license. Fortune 'Threat of Inadequate Knowledge in Prosecution of Business' Addis Ababa, March 25, 2018, at 21, 36. Further, in 2008 E.C., the Coffee and Tea Agency, had performance audit for coffee export conducted for the years between 2000 and 2007 Ethiopian calendar. Based on those findings of the audit, in not few cases, export standard coffee was purchased by licenses that were transferred to others. 
"changes that warrant amendments in the commercial registration pursuant to this Proclamation" with the same punishment. Sub-art (7) punishes refusal to provide information or obstruction of supervision works enforced based on the Proclamation or other legislation adopted under the Proclamation. These provisions were not provided for in the previous Proclamation in any form, and the description of the inclusion of those provisions as 'clarification' is indeed a misrepresentation.

There were two meetings to discuss the bill. The first meeting was between the House of Peoples' Representatives Commercial Affairs Standing Committee and experts of the Ministry of Trade, on June 29, 2016, and the second was a Public Hearing organised by the Standing Committee on July 5, 2016. During the June $29^{\text {th }}$ meeting, members of the House raised questions regarding the penal provisions. During the public hearing for the adoption of Proclamation No 686/2010, about four questions were raised by the representative of the Addis Ababa Chamber of Commerce, all of which were about the fairness and propriety of the severe penal provisions. ${ }^{133}$ The Ministry of Trade stated that it is aware of the problems and that even judges have difficulty applying the law. It had revised the law and reduced the punishments but, the Council of Ministers rejected the reduced sentence under the revised draft law. ${ }^{134}$

The records do not show substantive discussion in the public hearing. After the Committee's recommendations with a few editorial corrections, the HoPR adopted the bill into law. Despite several revisions and claims of research, there was no data presented supporting such legislative action.

\section{Remarks Regarding the Legislative Reform and the Use of Criminal Statistics}

As is the practice elsewhere, the executive controls the lawmaking process; the passing through the parliamentary process is a mere formality. ${ }^{135}$ In other systems, those legislations are initiated or effectively controlled by the Ministry of Justice. ${ }^{136}$ In Ethiopia, any agency initiates a bill it believes it is qualified to work on. Thus, the legal department transforms itself to legislative drafting

133 'Minutes of Meting of Commercial Affairs Standing Committee with Experts from Ministry of Trade on the Commercial Registration Amendment Draft Bill' (June 29, 2016, in Amharic), at 5, 6 .

${ }^{134}$ Id., at $12,13$.

${ }^{135}$ Ferrandez, supra note 54, at 79. The reduction of constitutional separation of power to a 'fiction' is modestly discussed by Assefa Fiseha (2015) "Legislative-Executive Relations in the Ethiopian Parliamentary System: Towards Institutional and Legal Reform" in J. de Visser, et. al., (Eds.) Constitution-Building in Africa (Baden-Baden: Nomos).

${ }^{136}$ Id., at 88 
department. The tax legislations, for instance, Proclamation No. 285/2002 and No. 286/2002 (including other tax legislation), were drafted principally by the Ministry of Finance and Economic Development and Ministry of Revenue. ${ }^{137}$ The continuously revised Commercial Registration and Business License Proclamations were drafted by the Ministry of Trade. ${ }^{138}$ The Vagrancy Control Proclamation No 384/2004 was drawn up by the then Ministry of Federal Affairs and Ministry of Justice. ${ }^{139}$ The Anti-Terrorism Proclamation No 652/2009 was prepared by the Federal Police and the National Intelligence and Security Services. ${ }^{140}$

Contrary to the requirements of the Council of Ministers Working Directives, none of the explanatory memorandums were sufficient in explaining the subject matter under revision. Often, there is no background research that explains the existing condition that necessitated the revision of the law and its possible economic, social and institutional implications; no declaration is attached whether the bills comply with the Constitution and other existing norms. In rare occasions where there is a background study, the research only explains the subject matter; it does not deal with the problem it is meant to address, nor does it attempt to justify such legislative action. Finally, none of the background studies contains empirical justification for the legislative action.

The laws highlighted in the preceding section have passed in short cuts. Draft bills are submitted to the Council of Ministers by the respective agencies. Obviously, the Council of Ministers is the most powerful organ with invisible hands reaching to the HoPR; thus, the drafting agency need to convince only the Council of Ministers. Once the Council is convinced, it forwards such bill to the HoPR. The House sends the bill to the relevant Standing Committee, such as, the Legal and Administrative Affairs Standing Committee, the National Security Standing Committee, and the Economic Affairs Standing Committee, and sometimes to joint Committees. Such Committee conducts public hearing; and sometimes there can be a hearing with experts so that the Committee can enhance its awareness on the subject. There is no record whether the draft bills were modified according to the proposals and comments made at such public hearing.

${ }^{137}$ Minutes of Meeting of the Economic Affairs and Legal Affairs Standing Committees with Resource Persons Regarding the Draft Bill on Value Added Tax' (November 7, 2001, in Amharic), at 2; 'Report and Recommendations from the Budget and Finance Affairs Standing Committee to have the Income Tax Draft Bill Adopted into Law' (July 4, 2002, in Amharic), at 1.

138 'Minutes of Public Hearing', supra note 117, at 2. 'Minutes of Public Hearing', supra note 77 , at 2 .

139 'Minutes of Public Hearing', supra note 76, at 1.

140 'Minutes of Public Hearing with Stakeholders', supra note 35, at 3. 
The concerned Standing Committee approves the draft with minor editorial changes, and recommends to the full House for the bill's adoption into law. No records show the parliament's inquiry into the validity of such actions based on normative and empirical justifications; and an inquiry into whether such norms comply with the principle of coherence. Nor is there a record of parliamentary debate on the bills by the full House. Once the bill comes back to the full House, it merely involves an up or down vote.

In drafting the bill, the relevant executive agencies are always partial to themselves in a skewed attempt to making their responsibilities easier. The most obvious is that they desire to enforce their administrative responsibilities at the threat of serious criminal sanctions to the individual. To this end, they incorporate various means that would ease their burden. For instance, the evidence that is often presented in prosecution for tax crimes is the Ethiopian Revenue and Customs Authority auditors' audit report. Therefore, arts 44 and 116 (of the and the Value Added Tax Proclamation No 285/2002 and Income Tax Proclamation 286/2002, respectively) provide that "the burden of proving that an assessment is excessive or that the decision of the authority is wrong lies on the person objecting to the assessment or decision." The Anti-Terrorism Proclamation (art 23) provides for the types of evidence that should be admitted by the court, which otherwise were not. The Vagrancy Control Proclamation (art 6(3)) makes the crime non-bailable offence. The Commercial Registration and Business License Proclamation criminally sanctions violations of any part of the Proclamation and the directive (as it may adopt from time to time). The contents of such directives, apparently, is left to the discretion of the agency.

In spite of the severe penal provisions stipulated in the legislation discussed above, and although the Federal Attorney General is the legal advisor of the Federal Government, its participation in the development of such legislation is minimal, and often totally absent. Article 6(5)(a) of the Federal Attorney General Establishment Proclamation No 943/2016 provides that the Attorney General shall "... ensure that draft laws prepared by government organs are consistent with the Constitution and federal laws". It also has the responsibility to "undertake legal reform studies." This should include legislative impact assessment.

There are also few important facts that surfaced several times. For instance, the punishment for commercial activities without a valid license has progressively increased; renewal of license is closely connected with the maximisation of revenue collection by the government for tax clearance is a precondition for license renewal. The so-called tax crimes entail severe criminal penalty and administrative measures. One can, therefore, observe two routes that concurrently punish tax crimes- one is through the tax legislation and the other is through the commercial registration proclamation. 


\section{Ending Remarks}

The discussion in the preceding sections shows that the lawmaker adopts laws upon the recommendation of agencies without first establishing the facts or without sufficient normative justification. Moreover, the legislature does not seem to balance its coercive actions with the rights of the individual to be protected against cruel, inhuman and degrading punishment. It also seems that the legislature does not take future circumstances into consideration. Most importantly, the lawmaker does not take post-lawmaking measures. These gaps show that the legislature usually fails to effectively undertake its duty, i.e. making good laws

The lawmaker uses the criminal law to protect certain legitimate interests when civil and administrative measures are not good enough to protect such interest. Once the criminal norm is in place, it is a matter of common sense that reports of its implementation should be presented for evaluation by the lawmaker. That is how criminal statistics come into play in legislative reform.

The various institutions have the responsibility to collect, analyse and interpret criminal statistics in their respective area of competence. The lawmaker revised various special penal legislation, such as, Vagrancy Control or AntiTerrorism Proclamations, or administrative legislation containing serious penal provision, such as, tax and commercial license related crimes. When these laws were revised, the lawmaker should have required the criminal statistics relating to the draft laws that were presented to it.

Upon the submission of draft laws, reference is made to the aggravated nature of the events that are alleged to be occurring, but never has any agency presented data. The draft bills are presented to parliament by various administrative agencies (rather than by the Ministry of Justice- currently Federal Attorney General), and they do not have the required criminal statistics. Institutions of justice, i.e., the Court, the Attorney General Office, and the Police, have thus failed to discharge their legal obligations of collection, analysis and interpretation of criminal statistics in the realm of their competence.

Indeed, the lawmaking process appears to be skewed in that, any administrative agency can draw a bill on which it claims competence and submit it to the Council of Ministers. From the Council of Ministers, the bill is sent to the House of Peoples' Representatives, which refers the draft law to the appropriate Standing Committee. Often, the Standing Committee recommends the adoption of a bill into law only with editorial changes. Once, it is presented to the full House, it merely appears to be an up or down vote without debate. Where the lawmaker and the executive are composed of members from a single political party, the 'shared' opinion, indeed comes before evidence and the latter may not be 'necessary.' 